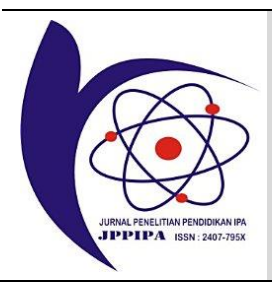

\title{
Development of Learning Devices Using Creative Problem Solving (CPS) Models on Static Electricity Material
}

\author{
Inriani $^{*}$, Azhar ${ }^{1}$, Muhammad Nasir $^{1}$ \\ ${ }^{1}$ Department of Physics Education Faculty of Theacher Training and Education, Riau University, Pekanbaru, Indonesia
}

DOI: $10.29303 /$ jppipa.v7iSpecialIssue.1119

\section{Article Info}

Received: October 24th, 2021

Revised: December 2nd, 2021

Accepted: December 7th, 2021

\begin{abstract}
The learning tools developed are science learning tools using creative problem solving models on static electricity material in the ninth grade of junior high school, in the form of lesson plans, student worksheet and test instruments. The purpose of this research is to produce science learning products with creative problem solving models that are valid and suitable for use in school. The data analysis technique in this study used descriptive analysis, by calculating the validation score for each assessment indicator. The results showed that the value of the validity of science learning tools using creative problem solving models was declared valid with an overall average score of 4.44 very valid categories. Likewise, the empirical validity of the test instrument obtained valid results for each item and was reliable at a value of 0.84 in the high category.
\end{abstract}

Keywords: Science Learning Devices; Creative Problem Solving Models; Static Electricity

Citation: Inriani, I., Azhar, A., \& Nasir, M. (2021). Development of Learning Devices Using Creative Problem Solving (CPS) Models on Static Electricity Material. Jurnal Penelitian Pendidikan IPA, 7(SpecialIssue), 213-217. https://doi.org/10.29303/jppipa.v7iSpecialIssue.1119

\section{Introduction}

The world of education plays an important role in the survival of a nation and state, because education can form quality human resources so that compete in the outside world. Education is one of the efforts to improve the quality of human resources, both individually and in groups (Sugianto \& Wijaya, 2018). According to the Law of the Republic of Indonesia No. 20 of 2003 states that education is a conscious and planned effort to create a learning atmosphere and learning process so that students actively develop their potential to have religious spiritual strength, selfcontrol, society, nation and state (Sisdiknas, 2013). One of the lessons that can develop students abilities is learning science.

Science learning is scientific knowledge about natural phenomena and requires truth testing and other scientific methods. According to Samatowa (2006), science learning is a science related to natural phenomena that are arranged systematically and regularly, generally accepted in the form of a collection of observations and experiments.

The results of the study by the international institution PISA (Program for International Student Assessment) that Indonesia achieved in 2015 was ranked 64th out of 69 participating countries (OECD, 2016). Meanwhile, in 2018 Indonesia's achievement was ranked 74th out of 79 participating countries (OECD, 2019). Judging from the fact that the quality of education in Indonesia is still far behind other countries, especially in scientific literacy. So the Ministry of Education and Culture itself made a breakthrough to make a leap in the field of education such as the 2013 curriculum.

The implementation of the 2013 curriculum to achieve science learning requires the role of a teacher to be the main subject. The educational process cannot be separated from learning activities in the classroom. Learning activities are largely determined by the collaboration between teachers and students (Satumah, 2017). However, science learning carried out by

\footnotetext{
*Email: inriani0721@student.unri.ac.id
} 
teachers is mostly still using conventional methods, where the teacher only conveys knowledge and students only receive or memorize the information received.

Based on the results of research conducted by Aji (2018) at SMPN 3 Wonogiri in ninth grade students, in the implementation of static electricity learning the results obtained by students on average are still low. Most of them have not exceeded the minimum completeness criteria and in the teaching and learning process students are passive and unmotivated in the learning process. Furthermore, based on research conducted by Deluhula (2017) at SMPN 5 Wonosari in the ninth grade that student learning outcomes are still relatively low on static electricity material, the average value obtained is 61.00 while the standard of completeness is 70 . The learning process is still centered to the teacher, students receive passive learning and only memorize the formulas on the static electricity material. In this problem, a learning device using the right model is needed to support the learning process to be more effective. In order to improve student learning outcomes and make students more active and teamwork, creative problem solving (CPS) models are needed. The creative problem solving (CPS) model is a learning model that focuses on teaching and problem solving skills, followed by skill strengthening, (Pepkin in Abduloh, et al., 2018).

Based on the description, the researcher is interested in conducting research on "The Development of Science Learning Devices Using Creative Problem Solving Models on Static Electricity Materials in Class Ninth Junior High Schools".

Table 1. Data Validity Criteria

\begin{tabular}{lllll}
\hline No & Scale & Criteria & Qualification & Information \\
\hline 1 & 5 & Very Valid & $\overline{\mathrm{X}}>\overline{\mathrm{X}}_{\mathrm{i}}+1.80 \mathrm{SB}_{\mathrm{i}}$ & $\overline{\mathrm{X}}>4.20$ \\
2 & 4 & Valid & $\overline{\mathrm{X}}_{\mathrm{i}}+0.60 \mathrm{SB}_{\mathrm{i}}<\overline{\mathrm{X}} \leq \overline{\mathrm{X}}_{\mathrm{i}}+1.80 \mathrm{SB}_{\mathrm{i}}$ & $3.40<\overline{\mathrm{X}} \leq 4,20$ \\
3 & 3 & Valid Enough & $\overline{\mathrm{X}}_{\mathrm{i}}-0.60 \mathrm{SB}_{\mathrm{i}}<\overline{\mathrm{X}} \leq \overline{\mathrm{X}}_{\mathrm{i}}+0.60 \mathrm{SB}_{\mathrm{i}}$ & $2.60<\overline{\mathrm{X}} \leq 3.40$ \\
4 & 2 & Not Valid & $\overline{\mathrm{X}}_{\mathrm{i}}-1.80 \mathrm{SB}_{\mathrm{i}}<\overline{\mathrm{X}} \leq \overline{\mathrm{X}}_{\mathrm{i}}-0.60 \mathrm{SB}_{\mathrm{i}}$ & $1.80<\overline{\mathrm{X}} \leq 2,60$ \\
5 & 1 & Very not Valid & $\overline{\mathrm{X}}_{\mathrm{i}}-1.80 \mathrm{SB}_{\mathrm{i}}<\overline{\mathrm{X}} \leq \overline{\mathrm{X}}_{\mathrm{i}}-0.60 \mathrm{SB}_{\mathrm{i}}$ & $\overline{\mathrm{X}} \leq 1.80$ \\
\hline
\end{tabular}

Description:

$\begin{array}{ll}\overline{\mathrm{X}}_{\mathrm{I}} & =1 / 2(\text { maximum score }+ \text { minimum score }) \\ \mathrm{SB}_{\mathrm{i}} & =1 / 6(\text { maksimum score-minimum score }) \\ \mathrm{X} & =\text { Empirical score }\end{array}$

After doing internal validity on all science learning device products with creative problem solving (CPS) models, namely in the form of learning implementation plans, student worksheets and test instruments, empirical validation was carried out on

\section{Method}

This study uses the type of research and development or Research and Development (R\&D) using the ADDIE model to produce creative problem solving (CPS) science learning tools. This development research aims to develop valid learning tools. The validation assessment sheet is the instrument used in this development research. The validation assessment sheet is obtained from the validator's assessment in the form of numbers, criticism and suggestions. The data obtained from the expert validation team is used as the basis for determining the feasibility of the creative problem solving (CPS) model of science learning tools.

The data analysis technique used is descriptive data analysis by describing quantitative data, namely the value of the learning device validation sheet by the validator team. Creative problem solving (CPS) model science learning device validation sheet using a Likert scale with five alternative answers. Learning devices are said to be valid if each validation assessment indicator is obtained a score of $>3.4$. If it does not meet the score, it must be repaired or revised on the indicator and then re-validated.

To find the average of each component used the following formula:

$$
\overline{\mathrm{X}}=\frac{\sum x}{n}
$$

Description:

$\overline{\mathrm{X}} \quad=$ Average score

$\sum \mathrm{x}=$ Total score

$\mathrm{N} \quad=$ Number of respondent

Decision making about the quality of learning products using the conversion level of achievement with a scale of five as Tabel 1.
(Bahtiar, 2020) test instruments, namely testing the validity of item questions, reliability, level of difficulty, power differentiator and distractor function. 


\section{Result and Discussion}

The products produced in this study are lesson plans, student worksheets and test instruments on static electricity material, while the results of the research are based on the stages of the ADDIE model, namely:

\section{Stage of Analysis}

At this stage, there are two things that are done, namely needs analysis and task analysis.

\section{The Needs Analysis}

Needs analysis is done by studying literature which aims to determine the main problems faced in accordance with the development objectives. Based on research conducted by Lestari, et al (2019), it was found that educators had problems in determining the learning model to be used in the material being taught. Most teachers use conventional models in learning so that learning does not vary which makes students feel bored and bored in learning. Then in making lesson plans, teachers also have difficulty in making them, due to the lack of understanding of teachers in developing lesson plans and having to adapt them to the facilities and infrastructure found in the school environment. Therefore, there is a need for science learning tools that can help teachers and students in science learning, namely creative problem solving (CPS) model science learning tools on static electricity material.

\section{Task Analysis}

The material chosen in this study was static electricity for class IX SMP. This is based on the problems that arise from several studies on the analysis of science learning problems on static electricity material. Static electricity is one of the materials that is difficult to understand for students. Lack of students' understanding of static electricity material results in low learning outcomes and has an impact on difficulty in solving problems. The task analysis stage consists of: (1) Material structure analysis; (2) Concept analysis; (3) Analysis of learning objectives

The formulation of learning objectives aims to facilitate the preparation of learning tools so that they are directed and systematic. Learning objectives must refer to basic competencies and from the objectives developed indicators of competency achievement.

\section{Design Stage}

The design stage is an advanced stage after the analysis stage is carried out. At this stage, the design of learning devices according to needs is carried out. The lesson plan developed in this research is about static electricity. The composition of the lesson plan is oriented to the creative problem solving model. This creative problem solving model lesson plan is based on a syllabus which is divided into five meetings. The guideline for preparing the lesson plan made by the researcher refers to Permendikbud No. 22 of 2016. The design of the lesson plan developed by the researcher looks like in Figure 1.

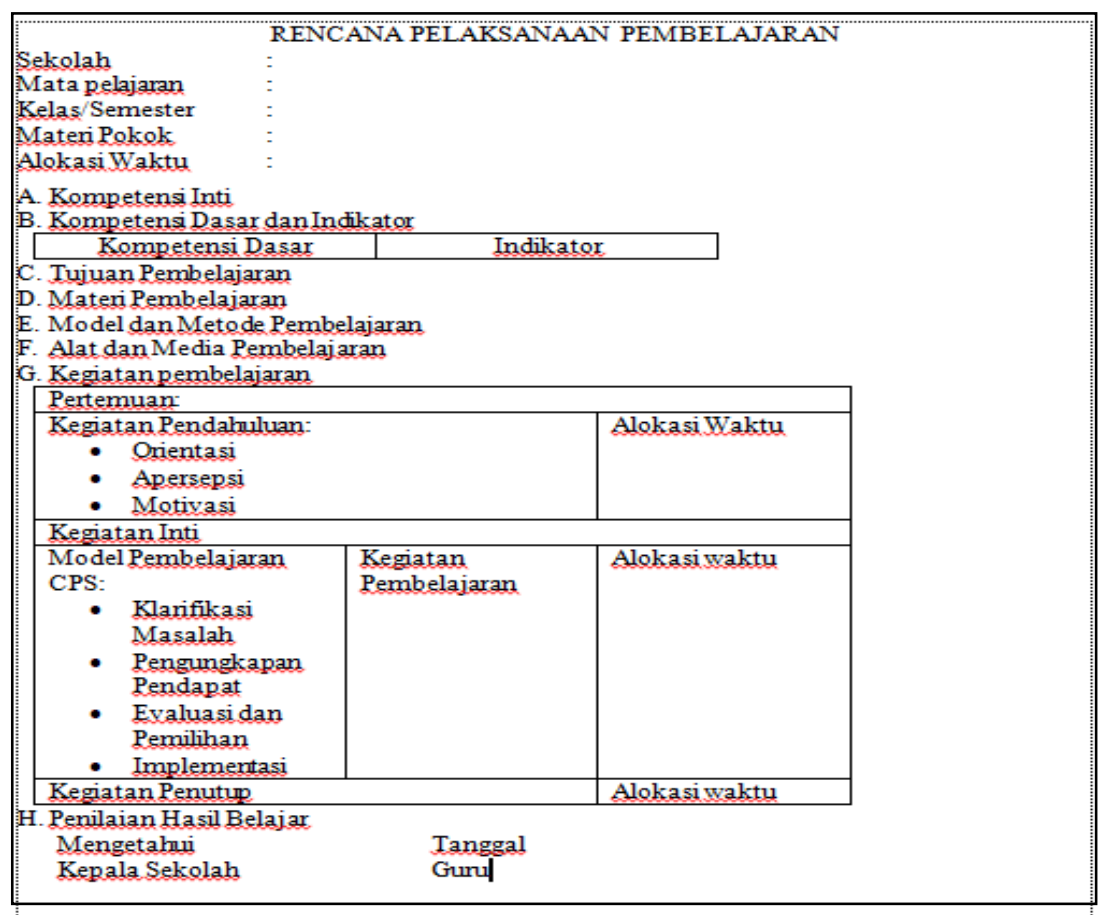

Figure 1. Lesson Plan Design 
Student worksheets are presented in the form of problem solving found in everyday life. Student worksheets consist of a series of student activities that are adapted to the creative problem solving model. The structure of the student worksheets made is the structure of the student worksheets which generally consist of the cover of the student worksheets, the title of the material, the objectives, the steps of the student activities that are adapted to the creative problem solving model, questions and conclusions. The form of the student worksheet developed by the researcher is shown in Figure 2.

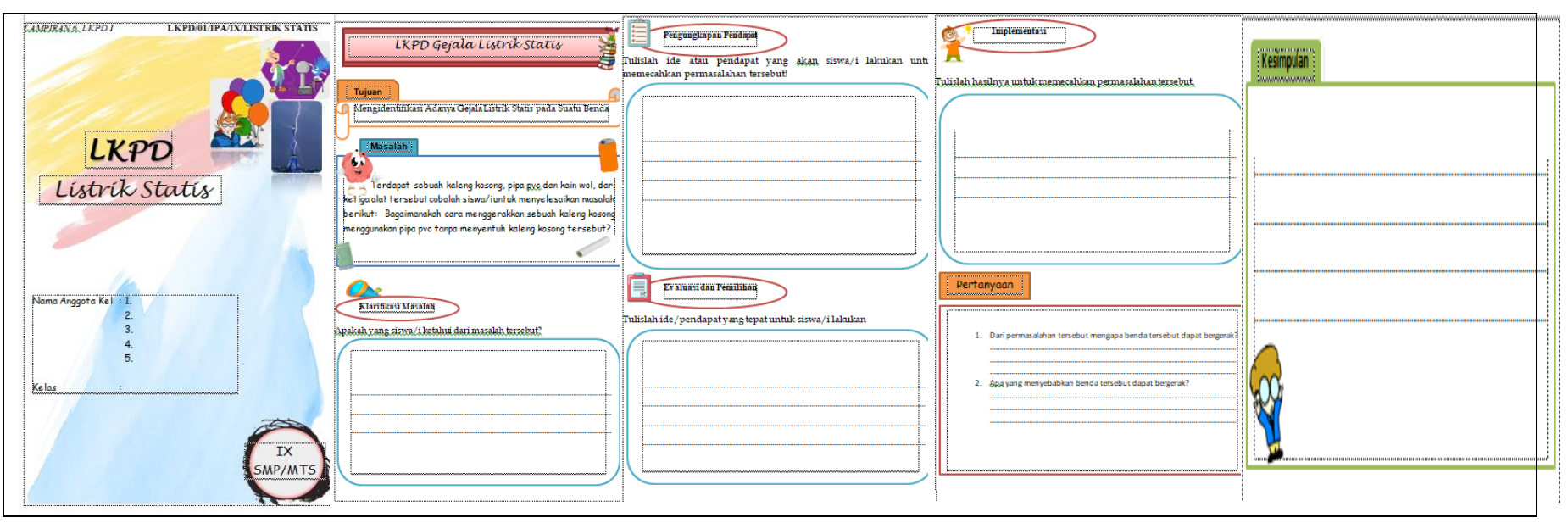

Figure 2. Student Worksheets Design

The test instrument developed in this study was arranged based on indicators. The test instrument consists of 20 questions with answer choices A, B, C and D. Researchers make questions in six levels of cognitive domains and indicators are adjusted to operational verbs in the cognitive domain. The indicators developed consisted of $\mathrm{C} 1$ with two questions, C2 with three questions, C3 with six questions, C4 with four questions, C5 with four questions and $\mathrm{C} 6$ with one question.

\section{Development Stage}

This development stage is a real step in realizing the design that has been determined and adapted to the needs that have been designed. Creative problem solving model science learning tools in the form of lesson plans, student worksheet and test instruments that have been developed before being used are tested for validity first. The learning tools were validated by a validator consisting of three lecturers of physics education, Faculty of Teacher Training and Education, University of Riau. Validation aims to get a valid creative problem solving model for science learning tools. The results of the validation of learning devices can be seen from Table 2 .

Table 2. Learning Device Validation Results

\begin{tabular}{|c|c|c|c|c|}
\hline No & Developed device & Rated aspect & Validation average & Category \\
\hline \multirow[t]{5}{*}{1} & Lesson plan & Lesson plan format & 4.50 & Very valid \\
\hline & & Content eligibility & 4.38 & Very valid \\
\hline & & Learning resources and assessment & 4.70 & Very valid \\
\hline & & Language & 4.30 & Very valid \\
\hline & Overall average & & 4.47 & Very valid \\
\hline \multirow[t]{4}{*}{2} & Student worksheet & Student worksheet format & 4.34 & Very valid \\
\hline & & Content eligibility & 4.39 & Very valid \\
\hline & & Language & 4.43 & Very valid \\
\hline & Overall average & & 4.39 & Very valid \\
\hline \multirow[t]{4}{*}{3} & Test instrument & Material & 4.56 & Very valid \\
\hline & & Construction & 4.34 & Very valid \\
\hline & & Language & 4.50 & Very valid \\
\hline & Overall average & & 4.47 & Very valid \\
\hline
\end{tabular}


From the data in Table 2, it is obtained that the overall average value of the validation is 4.44 with a very valid category, so that this learning tool is feasible to be used or implemented in schools.

After the learning device product is valid, the test instrument is empirically validated which is tested on students to determine the quality of the questions. The results on the validity of the items using the bisserial point formula, from 20 questions there are 20 valid questions with $r_{\text {count }}>0.39$. In the reliability search using the KR-21 formula, the resulting reliability value is 0.844 with a high category. At the level of difficulty there are 5 questions (25\%) with an easy level of difficulty, 10 questions $(50 \%)$ with a moderate level of difficulty, 5 questions (25\%) with a difficult level of difficulty. While on discriminatory power there are 2 questions $(10 \%)$ with sufficient discriminating power, 15 questions $(75 \%)$ with good discriminating power, 3 questions $(15 \%)$ with excellent discriminating power. And the distractor function has 2 problems, the distractor doesn't work properly. Apart from the internal validation of the test instrument being valid and feasible, the empirical validation also obtains valid and reliable criteria.

\section{Conclusion}

Based on the results of data analysis obtained by researchers, the development of science learning devices using creative problem solving (CPS) models on static electricity material in grade ninth junior high schools is declared valid in all aspects and can be used as teaching materials in the learning process at school.

\section{References}

Abduloh, U., Karomah, N., \& Hidayati, S. (2018). Peningkatan Kemampuan Pemecahan Masalah Matematika dalam Soal Literasi Matematika melalui Model CPS Kelas VIII H SMPN 9 Semarang: Prosiding Seminar Nasional Matematika. Retrieved from: https://journal.unnes.ac.id/sju/index.php/pris $\mathrm{ma} /$ article/view/20363/9666 [Indonesian]

Aji, A. (2018). Peningkatan Prestasi Belajar IPA melalui Pemanfaatan Media Pembelajaran dengan Pendekatan CTL pada materi Listrik Statis Siswa Kelas IX E SMPN 3 Wonogiri: Jurnal Sains Edukatika Indonesial, 1(2). Retrived from: https://jurnal.uns.ac.id/jsei/article/view/28046 [Indonesian]

Bahtiar. (2020). Evaluasi Pembelajaran Sains. Mataram: Sanabil [Indonesian]

Deluhula, J. (2017). Meningkatkan Aktivitas dan Hasil Belajar Siswa Melalui SEA pada Pembelajaran
Fisika Materi Listrik Statis di SMPN 5 Wonosari (Skripsi). Universitas Negeri Gorontalo, Gorontalo. [Indonesian]

Lestari, A., Sikumbang, D., \& T. Marpaung, R. (2019). Identifikasi Kendala Pendidik Dalam Pembelajaran IPA Terpadu Di SMP SeKabupaten Pringsewu. Jurnal Bioterdidik: Wahana Ekspresi Ilmiah, 7(2), 66-74. Retrieved from http://jurnal.fkip.unila.ac.id/index.php/JBT/ar ticle/view/17282 [Indonesian]

OECD. (2019) .PISA 2018 Results (Volume I): What Students Know and Can Do, PISA, OECD Publishing, Paris, doi: https://doi.org/10.1787/5f07c754-en

OECD. (2016). PISA 2015 Results (Volume I): What Students Know and Can Do, PISA, OECD Publishing, Paris, doi: https://doi.org/10.1787/5f07c754-en

Permendikbud (2016). Permendikbud Nomor 22 Tahun 2016 tentang Standar Proses Pendidikan Dasar Dan Menengah. Retrived from: https://bsnpindonesia.org/wp-content/...Lampiran.pdf [Indonesian]

Samatowa, U. (2006). Bagaimana Membelajarkan IPA di Sekolah Dasar. Jakarta: Departemen Pendidikan Nasional. [Indonesian]

Satumah. (2017). Upaya Meningkatkan Hasil Belajar Operasi Hitung Bilangan Bulat melalui Model NHT berbantuan Papan Bilangan Brilliant: Jurnal Riset dan Konseptual, 2(2),184. Doi: http://dx.doi.org/10.28926/briliant.v2i2.40 [Indonesian]

Sisdiknas. (2013). Undang-undang Republik Indonesia Nomor 20. Retrived from: .http://www.dikti.go.id/files/atur/UU202003Sisdiknas.pdf. [Indonesian]

Sugianto, S., \& Wijaya, P. A. (2018). Penerapan Model Pembelajaran Creative Problem Solving (CPS) Dengan Berbantuan Modul Elektronik Terhadap Motivasi Belajar Dan Kemampuan Berpikir Kreatif Di SMA Negeri 8 Pekanbaru Tahun 2017. PEKA, 6(1), 72-79. Retrieved from https://journal.uir.ac.id/index.php/Peka/articl e/view/1867 [Indonesian] 